The Analytic Tradition in Philosophy

$$
\text { -es }
$$





\title{
The Analytic Tradition in Philosophy
} \\ A NEW VISION
}

-SCOTT SOAMES. 
Copyright @ 2018 by Princeton University Press

Published by Princeton University Press, 41 William Street

Princeton, New Jersey 08540

In the United Kingdom: Princeton University Press, 6 Oxford Street

Woodstock, Oxfordshire OX20 1TR

press.princeton.edu

Background pattern courtesy of Shutterstock

All Rights Reserved

ISBN 978-0-691-16003-0

British Library Cataloging-in-Publication Data is available

This book has been composed in Baskerville 10 Pro

Printed on acid-free paper. $\infty$

Printed in the United States of America

10987654321 
FOR MARTHA, BRIAN, AND GREG

$$
\infty e
$$


